\title{
PENGARUH MODEL PEMBELAJARAN LEARNING CYCLE (5E) BERBASIS KEARIFAN LOKAL TERHADAP SIKAP DISIPLIN BELAJAR DAN HASIL BELAJAR IPA SISWA KELAS IV SD GUGUS V KECAMATAN SUKASADA
}

\author{
I Kadek Dwi Aditya', Made Sumantri², I Gede Astawan³ . \\ 1,2,3 Jurusan Pendidikan Dasar, Universitas Pendidikan Ganesha \\ Email: dwik394@gmai.com¹, madesumantripgsd@yahoo.co.id ${ }^{2}$ \\ igedeastawan@yahoo.com ${ }^{3}$
}

\begin{abstract}
ABSTRAK
Penelitian ini bertujuan untuk mengetahui 1) perbedaan sikap disiplin belajar dan hasil belajar IPA secara simultan antara siswa secara simultan yang mengikuti model pembelajaran learning cycle (5E) berbasis kearifan lokal dan siswa yang mengikuti pembelajaran konvensional. 2) perbedaan sikap disiplin belajar antara siswa yang mengikuti model pembelajaran learning cycle (5E) berbasis kearifan lokal dan siswa yang mengikuti pembelajaran konvensional, dan 3) perbedaan hasil belajar IPA antara siswa yang mengikuti model pembelajaran learning cycle $(5 E)$ berbasis kearifan lokal dan siswa yang mengikuti pembelajaran konvensional. Penelitian ini merupakan penelitian quasi experiment dengan desain nonequivalent post-test only control group. Jumlah populasi dalam penelitian ini adalah 209 orang dan sampel penelitian berjumlah 55 orang yang diambil dengan teknik group desain random sampling. Data sikap disiplin belajar siswa dikumpulkan menggunakan metode non tes berupa lembar kuesioner dan data hasil belajar IPA dikumpulkan menggunakan tes pilihan ganda. Data dianalisis dengan teknik Manova. Hasil penelitian menunjukkan bahwa: 1) secara simultan, terdapat perbedaan sikap disiplin belajar dan hasil belajar IPA antara kelompok siswa yang mengikuti model pembelajaran learning cycle $(5 \mathrm{E})$ berbasis kearifan lokal dan antara kelompok siswa yang mengikuti model pembelajaran konvensional yang dibutikan dengan nilai signifikasi sebesar 0,004 <0,05. 2) terdapat perbedaan sikap disiplin belajar antara kelompok siswa yang mengikuti model pembelajaran learning cycle (5E) berbasis kearifan lokal dan kelompok siswa yang mengikuti model pembelajaran konvensional yang dibuktikan dengan nilai signifikansi $0,017<0,05$. 3) terdapat perbedaan hasil belajar antara kelompok siswa yang mengikuti model pembelajaran learning cycle (5E) berbasis kearifan lokal dan antara kelompok siswa yang mengikuti model pembelajaran konvensional yang dibuktikan dengan nilai signifikansi sebesar 0,036 $<0,05$. Berdasarkan temuan tersebut, dapat disimpulkan bahwa model pembelajaran learning cycle (5E) berbasis kearifan lokal berpengaruh positif terhadap sikap disiplin belajar dan hasil belajar IPA siswa.
\end{abstract}

Kata kunci : learning cycle (5E), kearifan lokal, Sikap disiplin , IPA.

Pengaruh Model Pembelajaran Learning Cycle (5e) Berbasis Kearifan Lokal Terhadap 


\begin{abstract}
This study aims to determine (1) the difference in learning discipline attitudes and simultaneous learning outcomes of science between students who follow the learning cycle learning model (5E) based on local wisdom and students who follow conventional learning (2) differences in the attitude of learning discipline between students who follows the learning cycle learning model $(5 \mathrm{E})$ based on local wisdom and students who follow conventional learning (3) differences in science learning outcomes between students who follow the learning cycle learning model (5E) based on local wisdom and students who follow conventional learning. This research is a quasiexperimental study with a nonequivalent post-test only control group design. The population in this study was 209 people and the study sample was 55 people taken by group random sampling design technique. Data on students' learning discipline attitudes were collected using non-test methods in the form of questionnaires and science learning outcomes data were collected using multiple choice tests. Data were analyzed by the Manova technique. The results showed that: 1) simultaneously, there were differences in learning discipline attitudes and science learning outcomes of students who followed the learning cycle learning model (5E) based on local wisdom with students who followed conventional learning $0.004<0.05,2$ ) there are differences in the discipline of learning attitudes between students who follow the learning cycle learning model (5E) based on local wisdom with students who follow conventional learning $0.017<0.005,3)$ there are differences in learning outcomes between students follow the learning cycle (5E) learning model based on local wisdom with students with students who take conventional learning $0,036<0,05$. Based on these findings, it can be concluded that the learning cycle model $(5 \mathrm{E})$ is based on influential local wisdom positive towards learning discipline attitudes and student science learning outcomes.
\end{abstract}

Keywords: learning cycle (5E), local wisdom, discipline attitude, science.

\title{
PENDAHULUAN
}

Pendidikan merupakan kebutuhan yang sangat penting bagi manusia, untuk membentuk Sumber Daya Manusia (SDM) yang berkualitas secara intelektual, spiritual dan mandiri dalam pembangunan bangsa dan negara. SDM berkualitas diyakini mampu bersaing dengan berbagai negara di dunia. Dalam Undang-Undang Sisdiknas No. 20 Tahun 2003 tentang Sistem Pendidikan Nasional, disebutkan bahwa pendidikan adalah usaha sadar dan terencana untuk mewujudkan suasana belajar dan proses pembelajaran agar peserta didik secara aktif mengembangkan potensi dirinya untuk memiliki kekuatan spiritual keagamaan, pengendalian diri, kepribadian, kecerdasan, akhlak mulia, kecerdasan, serta keterampilan yang diperlukan oleh dirinya dan masyarakat, bangsa dan negara.

Proses pembelajaran di SD dilaksanakan berdasarkan pada kurikulum yang berlaku. Dalam Undang-Undang No. 20 Tahun 2003 tentang Sistem Pendidikan Nasional, dipaparkan "Pengaturan mengenai tujuan, isi dan bahan pelajaran serta cara yang digunakan sebagai pedoman penyelenggaraan kegiatan pembelajaran untuk mencapai tujuan pendidikan tertentu disebut dengan kurikulum". Sebagai kurikulum yang berlaku dalam Sistem Pendidikan Indonesia, Kurikulum 2013 yang disebut juga kurikulum berbasis karakter ini merupakan sebuah pembelajaran yang menekankan pada aspek afektif dan kompetensi yang ingin dicapai adalah kompetensi yang berimbang antara sikap, keterampilan, dan pengetahuan (Putri, 2018).

Pengaruh Model Pembelajaran Learning Cycle (5e) Berbasis Kearifan Lokal Terhadap

Sikap Disiplin Belajar dan hasil belajar ipa siswa kelas iv sd gugus v Kecamatan sukasada 
Dalam Permendikbud RI Nomor 24 Tahun 2016 dicantumkan tentang Kompetensi Inti dan Kompetensi Dasar, dijelaskan bahwa kompetensi dasar merupakan kemampuan dan materi pembelajaran minimal yang harus dicapai peserta didik untuk suatu mata pelajaran pada masing-masing satuan pendidikan yang mengacu pada kompetensi inti. Kegiatan pembelajaran perlu menggunakan prinsip-prinsip, yaitu: (1) berpusat pada siswa, (2) mengembangkan kreativitas siswa, (3) menciptakan pengalaman belajar yang menyenangkan, kontekstual, efektif, efisien dan bermakna dan (4) bermuatan nilai, etika, estetika, logika, dan kinestika. "Belajar merupakan pengembangan aspek kognitif yang meliputi struktur, isi, dan fungsi"(Shoimin, 2014:58). "Mengajar harus selalu dikaitkan dengan belajar yang merupakan full-contact action yang senantiasa melibatkan semua aspek kepribadian manusia-pikiran, perasaan, bahasa tubuh, pengetahuan, sikap awal dan persepsi masa mendatang"(Astawan dan Rati, 2016:3).

Pada kenyataannya, diketahui bahwa proses pembelajaran di SD khususnya pelajaran IPA masih bersifat teoretis yaitu lebih berpusat pada guru (teacher centered). Proses pendidikan yang demikian, lebih berorientasi untuk mentransfer ilmu pengetahuan dari guru ke peserta didik. Pembelajaran di SD juga belum sepenuhnya dilaksanakan secara aktif dan kreatif dalam melibatkan siswa serta belum menggunakan berbagai model pembelajaran yang bervariasi. Kebanyakan pembelajaran terpaku pada buku teks sebagai satu-satunya sumber pembelajaran. Hal tersebut terlihat pada hasil observasi yang dilaksanakan di kelas IV SDN Gugus V Kecamatan Sukasada. Sebagai dampak pembelajaran demikian, terlihat dari nilai UTS siswa yang masih rendah. Berdasarkan hasil dokumentasi nilai rata-rata ulangan harian siswa kelas IV pada mata pelajaran IPA adalah sebagai berikut. SD N 1 Sambangan yaitu 68,92, SD N 2 Sambangan nilai rata-rata ulangan harian siswa adalah 67,30, untuk SD N 3 Sambangan nilai rata-rata ulangan harian siswa adalah 66,75 , SD N 1 Panji nilai rata-rata ulangan harian siswa adalah 64,58, SD N 2 Panji nilai rata-rata ulangan harian siswa 63,96, SD N 3 Panji nilai rata-rata ulangan harian 67,26, SD N 4 Panji nilai rata-rata ulangan harian 66,56, SD N 5 Panji nilai rata-rata ulangan siswa 66,82, Begitu pula dengan SD N 6 Panji nilai rata-rata ulangan siswa 66,57 dan KKM yang harus dicapai siswa dari ke 9 SD ini adalah 70. Dari rata-rata hasil belajar siswa tersebut menunjukkan bahwa siswa pada mata pelajaran IPA masih belum mencapai KKM. Hasil tersebut dipengaruhi oleh penggunaan metode ceramah dalam sebagian besar pembelajaran sehingga pembelajaran terkesan satu arah yang nantinya dapat mengurangi keaktifan siswa dalam mengaplikasikan pengetahuannya. Kurangnya menerapkan model pembelajaran yang inovatif, kreatif dan efektif dan pembelajaran yang belum dikaitkan dengan kearifan lokal membuat siswa cepat bosan. Kondisi demikian apabila dibiarkan akan berdampak kurang optimal terhadap kualitas pembelajaran IPA. Berdasarkan hasil observasi hari senin, 7 januari 2019 yang dilaksanakan di kelas IV SDN Gugus V Kecamatan Sukasada terkait sikap disiplin belajar, diperoleh hasil yaitu 1) banyak siswa yang sibuk bermain dan mengobrol dengan temannya sehingga tidak mendengarkan penjelasan guru, 2) siswa masih kurang sopan dalam berbicara maupun bersikap dalam mengungkapkan pendapatnya dalam kelompok, 3) proses penyerapan informasi saat belajar tidak maksimal karena siswa tidak memiliki kedisiplinan belajar, 4) sikap disiplin belajar yang kurang juga membuat siswa menjadi tidak siap ketika ulangan mendadak, karena waktu yang digunakan untuk belajar malah dimanfaatkan untuk bermain, 5) terdapat siswa yang terbiasa terlambat bahkan lupa mengerjakan tugas-tugasnya keterlambatan tersebut akan berujung kepada ketidakdisiplinan

Pengaruh Model Pembelajaran Learning Cycle (5e) Berbasis Kearifan Lokal Terhadap

Sikap Disiplin Belajar dan hasil belajar ipa siswa kelas iv sd gugus v Kecamatan sukasada 
dalam belajar. Kondisi ini tentu berdampak kurang baik pada proses pembelajaran siswa. Pembelajaran menjadi tidak efektif dan kondusif sehingga nantinya dapat mengakibatkan kurang maksimalnya hasil belajar IPA siswa.

Untuk mengatasi permasalahan tersebut, maka dibutuhkan model pembelajaran yang inovatif yang dapat meningkatkan kualitas proses pembelajaran, agar situasi pembelajaran menjadi menyenangkan, aktif, dan bermakna bagi siswa. Salah satu model pembelajaran yang mendukung adalah model pembelajaran learning cycle (5E) berbasis kearifan lokal."Siklus belajar (5E) merupakan pengembangan dari model siklus belajar eksplorasi, pengenalan konsep dan aplikasi konsep"(Sadia, 2014:23).

Melalui model pembelajaran learning cycle (5E) menekankan kepada siswa dengan memberikan pengalaman langsung dalam memahami materi pelajaran dan memberikan kesempatan kepada siswa untuk aktif membangun pengetahuannya sendiri. Cardak, dkk. (dalam Sadia, 2014:23) mengartikan bahwa model siklus belajar 5E merupakan suatu model pembelajaran yang berorientasi pada filsafat konstruktivisme. Model pembelajaran siklus memberikan kesempatan kepada peserta didik mengkonstruksi pengetahuan dan pengalaman mereka sendiri dengan terlibat secara aktif mempelajari materi secara bermakna dengan bekerja dan berpikir baik secara individu maupun kelompok. Ciri khas model pembelajaran learning cycle (5E) ini ialah setiap siswa secara individu belajar materi pembelajaran yang sudah dipersiapkan guru. Kemudian, hasil belajar individual dibawa ke kelompok-kelompok untuk didiskusikan oleh anggota kelompok dan semua anggota kelompok bertanggung jawab secara bersama-sama atas keseluruhan jawaban.

Proses pembelajaran dengan model pembelajaran learning cycle (5E) ini akan sangat bermakna apabila didukung dengan konsep kearifan lokal. "Kearifan lokal merupakan bagian dari kebudayaan yang sudah mentradisi, menjadi milik kolektif dan bersifat fungsional untuk memecahkan masalah, setelah melewati pengalaman dalam dimensi ruang dan waktu secara berkelanjutan" (Suja, 2010:2). Kearifan lokal merupakan upaya untuk membudayakan nilai-nilai lokal di daerah tempat tinggal siswa, nilai-nilai kearifan lokal tersebut antara lain Tri Hita Karana, Tri Kaya Parisuda, Tatwam Asi, Salunglung Sabayantaka, Paras Paros Sarpanaya, Bhineka Tunggal Ika, Menyama Braya. Nilai kearifan lokal tersebut nantinya agar dapat diaplikasikan oleh siswa. Dengan demikian, diharapkan nantinya siswa dapat menjadi anggota masyarakat yang aktif, berbudaya dan mampu bersosialisasi dalam masyarakatnya (Yuniari, 2014). Perpaduan nilai kearifan lokal dalam proses pembelajaran memberikan pembelajaran yang bermuatan pendidikan etika untuk berpikir, berbicara dan berperilaku yang baik sehingga pembelajaran menjadi lebih bermakna bagi siswa dan berdampak positif.

Secara empirik penelitian yang dilakukan oleh Suniasih, dkk. (2013) menyimpulkan bahwa ada pengaruh model pembelajaran learning cycle (5E) terhadap sikap ilmiah dan hasil belajar IPA siswa kelas IV SD Negeri 5 Pedungan. Penelitian lainnya yang dilakukan oleh Yopiani, dkk. (2013) menyimpulkan bahwa terdapat pengaruh model learning cycle (5E) (Engagement, Eksploration, Eksplanation, Elaboration, Evaluation) berbantuan media grafis terhadap hasil belajar PKn kelas V SDN 1 Kesiman. Penelitian lainnya yang dilakukan oleh Dewi, dkk. (2013), menyimpulkan model pembelajaran siklus belajar learning cycle (5E) berpengaruh positip dan signifikan terhadap hasil belajar IPA siswa kelas V SD N 26 Pemecutan Denpasar Barat.Berdasarkan paparan di atas, maka diadakan penelitian ini dengan menggunakan model learning cycle $(5 \mathrm{E})$ berbasis kearifan lokal dalam mata pelajaran

Pengaruh Model Pembelajaran Learning Cycle (5e) Berbasis Kearifan Lokal Terhadap

Sikap Disiplin Belajar dan hasil belajar ipa siswa kelas iv sd gugus v Kecamatan sukasada 
IPA. Dengan model learning cycle (5E) berbasis kearifan lokal ini diharapkan dapat memengaruhi sikap disiplin belajar dan proses pembelajaran menjadi menyenangkan dan kondusif, serta hasil belajar siswa dalam mata pelajaran IPA yang diharapkan dapat tercapai. Untuk itu penelitian ini berjudul "Pengaruh Model Learning Cycle (5E) Berbasis Kearifan Lokal Terhadap Sikap Disiplin Belajar dan Hasil Belajar IPA Siswa Kelas IV di SD Gugus V Kecamatan Sukasada".

\section{METODE}

Penelitian ini mengikuti desain Penelitian kuasi eksperimen dengan rancangan yang digunakan adalah non equivalent post-test only control group design (Agung, 2014:163). Populasi dari penelitian ini adalah seluruh kelas IV SDN Gugus V Sukasada Tahun Ajaran 2018/2019. Adapun seluruh SDN yang tergabung dalam Gugus V Sukasada adalah (1) SDN 1 Sambangan, (2) SDN 2 Sambangan, (3) SDN 3 Sambangan, (4) SDN 1 Panji, (5) SDN 2 Panji, (6) SDN 3 Panji, (7) SDN 4 Panji, (8) SDN 5 Panji, (9) SDN 6 Panji. Berdasarkan karakteristik populasi dan tidak bias dilakukannya pengacakan individu, maka pengambilan sampel pada penelitian ini dilakukan dengan teknik random sampling.

Menurut Koyan (2012:30) menyatakan bahwa "sampel penelitian merupakan bagian dari populasi". Berdasarkan penentuan jumlah sampel dari populasi yang ada, jumlah sampel kelas IV di SD Negeri 4 Panji dan kelas IV di SD Negeri 5 Panji memenuhi syarat. Menurut Surakhmad (dalam Agung, 2017), "Untuk pedoman umum saja dapat dikaitkan bahwa populasi cukup homogen terhadap ukuran populasi 100-1000, dapat digunakan sampel sebesar $25 \%$." Sehingga diperoleh jumlah sampel $209 \times 25 \%=52$ orang. Jadi, jumlah minimal sampel yang harus diambil adalah 52 orang. Kelompok eksperimen dalam penelitian ini dikenai perlakuan berupa model pembelajaran learning cycle $5 E$, Sedangkan pada kelas kontrol tidak mendapat perlakuan namun dibelajarkan pembelajaran konvensional, yaitu pembelajaran yang berlangsung sehari-hari di kelas kontrol yang dilaksanakan oleh guru, kemudian kedua kelompok dikenai pengukuran yang sama. Variabel bebas yang ditetapkan dalam penelitian ini adalah model pembelajaran. Model pembelajaran dipilah menjadi dua, yaitu model pembelajaran learning cycle $5 E$ yang dikenakan pada kelompok eksperimen dan model pembelajaran konvensional dikenakan pada kelompok kontrol.Sedangkan variabel terikat yang ditetapkan dalam penelitian ini adalah sikap disiplin belajar dan hasil belajar IPA. Pengumpulan data dalam penelitian ini meliputi: (1) sikap disiplin belajar dan (2) hasil belajar IPA. Dalam penelitian ini di dukung oleh instrument-instrumen penelitian,"instrumen yang digunakan untuk mengumpulkan data harus menjamin kebenaran data" (Candiasa, 2010:21). Data sikap disiplin belajar dikumpulkan menggunakan kuesioner. Kuesioner tersebut terdapat pernyataan dengan masing-masing 4 pilihan yaitu Sangat Setuju (SS), Setuju (S), Tidak Setuju (ST), Sangat Tidak Setuju (STS). Pemberian skor pada setiap item $S S=4, S=3, T S=2$, $S T S=1$ untuk pernyaataan positif. Untuk pernyataan negatif diberi skor $S S=1, S=2,, T S=3, S T S=4$. Skor respon siswa diperoleh dengan menjumlahkan skor yang diperoleh siswa untuk setiap item. Data hasil belajar IPA dikumpulkan dengan menggunakan tes yaitu tes uraian. Uji validitas sikap disiplin belajar menunjukkan 25 butir soal kuesioner sikap disiplin belajar dan 25 butir soal hasil belajar IPA dikategorikan valid. Untuk uji reliabilitas sikap ilmiah dan hasil belajar IPA dikategorikan tinggi. Sebelum melakukan analisis data terlebih dahulu dilakukan uji prasyarat analisis yaitu (a) uji normalitas, (b) uji homogenitas varian, (c) Uji Korelasi Antar Variabel Terikat, setelah itu

Pengaruh Model Pembelajaran Learning Cycle (5e) Berbasis Kearifan Lokal Terhadap

Sikap Disiplin Belajar dan hasil belajar ipa siswa kelas iv sd gugus v Kecamatan sukasada 
dilakukan uji hipotesis menggunakan uji Manova, perhitungan dilakukan dengan berbantuan program SPSS 17.0 for windows.

\section{HASIL DAN PEMBAHASAN}

Hasil

Data hasil penelitian ini merupakan skor sikap disiplin belajar dan hasil belajar IPA sebagai akibat dari penerapan model pembelajaran learning cycle (5E) pada kelompok eksperimen dan pembelajaran konvensional pada kelompok kontrol. Data sikap disiplin belajar kelompok siswa yang mengikuti pembelajaran melalui model pembelajaran learning cycle $5 E$ menunjukkan rata-rata sikap disiplin belajar siswa $\bar{X}=85,89$. Sedangkan data sikap disiplin belajar kelompok siswa yang mengikuti pembelajaran konvensional menunjukkan nilai rata-rata siswa $\bar{X}=81,61$. Data hasil belajar IPA kelompok siswa yang mengikuti pembelajaran melalui model pembelajaran learning cycle $(5 \mathrm{E})$ berbasis kearifan lokal menunjukkan rata-rata hasil belajar IPA siswa $\bar{X}=67,33$. Sedangkan data hasil belajar IPA kelompok siswa yang mengikuti pembelajaran konvensional menunjukkan nilai rata-rata $\bar{X}=59,36$.

Berdasarkan hasil uji prasyarat analisis data, uji normalitas Kolmogorov-Smirnov dan Shapiro-Wilk hasil analisis menunjukkan bahwa nilai sikap disiplin belajar eksperimen $=0,200$ dan 0,248 , nilai sikap disiplin belajar Kontrol $=0,166$ dan 0,83 , nilai hasil belajar IPA eksperimen $=0,77$ dan 0,101, nilai hasil belajar IPA kontrol $=0,081$ dan 0,81 keseluruhan nilai signifikansi dari perhitungan Kolmogorov-Smirnov dan Shapiro-Wilk lebih tinggi dari 0,050. Hal ini berarti, data: (1) hasil belajar IPA siswa yang mengikuti model learning cycle (5E) berbasis kearifan lokal, (2) sikap disiplin belajar yang mengikuti model learning cycle (5E) berbasis kearifan lokal, (3) hasil belajar IPA siswa yang mengikuti model pembelajaran konvensional, dan (4) sikap disiplin belajar siswa yang mengikuti model pembelajaran konvensional, berasal dari populasi yang berdistribusi secara normal. Uji homogenitas diperoleh hasil bahwa varians data sikap disiplin belajar dan hasil belajar IPA memenuhi varians yang homogen karena hasil adalah uji Levene's test of Equality of Error Varians menunjukkan harga $F=0,556 ; p>0,05$. Maka pengujian dilanjutkan dengan menguji hipotesis terhadap hipotesis nol. Pengujian hipotesis penelitian ini dilakukan untuk menguji hipotesis, yaitu Uji Manova.

\section{Tabel 1}

Hasil Uji Manova

\section{Multivariate Test}

\section{Partial}

Eta

\begin{tabular}{llrrrrrr} 
Effect & & Value & $F$ & Hypothesis df & Error df & Sig. Squared \\
\hline Intercep & Pillai's Trace & .995 & $5.050 \mathrm{E3}^{\mathrm{a}}$ & 2.000 & 52.000 & .000 & .995 \\
\cline { 2 - 8 } & Wilks' Lambda & .005 & $5.050 \mathrm{E3}^{\mathrm{a}}$ & 2.000 & 52.000 & .000 & .995 \\
\cline { 2 - 7 } & Hotelling's Trace & 194.238 & $5.050 \mathrm{E3}^{\mathrm{a}}$ & 2.000 & 52.000 & .000 & .995
\end{tabular}

Pengaruh Model Pembelajaran Learning Cycle (5e) Berbasis Kearifan Lokal Terhadap 


\begin{tabular}{llrrrrrr} 
& Roy's Largest & 194.238 & $5.050 \mathrm{E3}^{\mathrm{a}}$ & 2.000 & 52.000 & .000 & .995 \\
\hline koot & .195 & $6.298^{\mathrm{a}}$ & 2.000 & 52.000 & .004 & .195 \\
\cline { 2 - 8 } & Pillai's Trace & .805 & $6.298^{\mathrm{a}}$ & 2.000 & 52.000 & .004 & .195 \\
\cline { 2 - 8 } & Wilks' Lambda & .242 & $6.298^{\mathrm{a}}$ & 2.000 & 52.000 & .004 & .195 \\
\cline { 2 - 8 } & Hotelling's Trace & .242 & $6.298^{\mathrm{a}}$ & 2.000 & 52.000 & .004 & .195 \\
\cline { 2 - 6 } & $\begin{array}{l}\text { Roy's Largest } \\
\text { Root }\end{array}$ & & & & &
\end{tabular}

Dari Tabel 1 diketahui bahwa untuk semua nilai F Pillai's Trace, Wilks' Lambda, Hotelling's Trace, Roy's Largest Root masing-masing dengan F = 6,298 dengan taraf signifikansi 0,000. Ini berarti $F=6,298 ; 0,004<0,05$, sehingga $\mathrm{H}_{0}$ ditolak dan $\mathrm{H}_{1}$ diterima.

Berdasarkan hasil analisis uji hipotesis 1 dapat disimpulkan bahwa terdapat perbedaan sikap disiplin belajar dan hasil belajar IPA secara simultan antara siswa yang mengikuti model pembelajaran learning cycle (5E) berbasis kearifan lokal dan siswa yang mengikuti pembelajaran konvensional pada siswa kelas IV SD Gugus V KecamatanSukasada.

\section{Tabel 2}

Uji Tests of Between-Subjects Effects

\begin{tabular}{llccccc} 
Source & $\begin{array}{l}\text { Dependent } \\
\text { Variable }\end{array}$ & $\begin{array}{c}\text { Type III Sum } \\
\text { of Squares }\end{array}$ & df & $\begin{array}{c}\text { Mean } \\
\text { Square }\end{array}$ & $\mathrm{F}$ & Sig. \\
\hline $\begin{array}{l}\text { Correcte } \\
\text { d Model }\end{array}$ & $\begin{array}{l}\text { Sikap_Disiplin_Bel } \\
\text { ajar }\end{array}$ & $291.088^{\mathrm{a}}$ & 1 & 291.088 & 6.125 & .017 \\
\cline { 2 - 7 } & Hasil_belajar_IPA & $1003.646^{\mathrm{c}}$ & 1 & 1003.646 & 4.616 & .036 \\
\hline $\begin{array}{l}\text { Intercept } \\
\text { Sikap_Disiplin_Bel } \\
\text { ajar }\end{array}$ & 383814.724 & 1 & $\begin{array}{c}383814.72 \\
4\end{array}$ & $8.077 \mathrm{E3}$ & .000 \\
\cline { 2 - 7 } & Hasil_belajar_IPA & 218131.210 & 1 & $\begin{array}{c}218131.21 \\
0\end{array}$ & $1.003 \mathrm{E3}$ & .000 \\
\hline $\begin{array}{l}\text { Kelompo } \\
\mathrm{k}\end{array}$ & $\begin{array}{l}\text { Sikap_Disiplin_Bel } \\
\text { ajar }\end{array}$ & 291.088 & 1 & 291.088 & 6.125 & .017 \\
\cline { 2 - 7 } & Hasil_belajar_IPA & 1003.646 & 1 & 1003.646 & 4.616 & .036
\end{tabular}

\section{Tabel 3}

Pairwise Comparisons

\begin{tabular}{|c|c|c|c|c|c|c|}
\hline \multirow{2}{*}{$\begin{array}{l}\text { Dependent } \\
\text { Variable }\end{array}$} & \multirow{2}{*}{ (I) Kelompok } & \multirow{2}{*}{$\begin{array}{c}(\mathrm{J}) \\
\text { Kelompok }\end{array}$} & \multirow{2}{*}{$\begin{array}{l}\text { Mean } \\
\text { Differen } \\
\text { ce (I-J) }\end{array}$} & \multirow{2}{*}{$\begin{array}{l}\text { Std. } \\
\text { Error }\end{array}$} & \multirow{2}{*}{ Sig. ${ }^{a}$} & $\begin{array}{c}\text { 95\% Confidence } \\
\text { Interval for } \\
\text { Difference }^{a}\end{array}$ \\
\hline & & & & & & $\begin{array}{ll}\text { Lower } & \text { Upper } \\
\text { Bound } & \text { Bound }\end{array}$ \\
\hline
\end{tabular}

Pengaruh Model Pembelajaran Learning Cycle (5e) Berbasis Kearifan Lokal Terhadap

Sikap Disiplin Belajar dan hasil belajar ipa siswa kelas iv sd gugus v Kecamatan sukasada 


\begin{tabular}{lllrrrrr} 
Sikap_Disiplin_Bel & Eksperimen & Kontrol & $4.602^{*}$ & 1.859 & .017 & .872 & 8.331 \\
\cline { 2 - 7 } ajar & Kontrol & Eksperimen & $-4.602^{*}$ & 1.859 & .017 & -8.331 & -.872 \\
\hline Hasil_belajar_IPA & Eksperimen & Kontrol & $8.545^{*}$ & 3.977 & .036 & .568 & 16.522 \\
\cline { 2 - 8 } & Kontrol & Eksperimen & $-8.545^{*}$ & 3.977 & .036 & -16.522 & -.568
\end{tabular}

Berdasarkan Tabel 2, diperoleh nilai signifikasi sikap disiplin belajar pada kolom kelompok sebesar 0,017 dan lebih kecil dari 0,05 $(0,017<0,05)$, sehingga dapat disimpulkan bahwa $\mathrm{H}_{0}$ ditolak dan $\mathrm{H}_{1}$ diterima. Jadi dapat disimpulkan bahwa, hasil analisis uji hipotesis 2 terdapat perbedaan sikap disiplin belajar antara siswa yang mengikuti model pembelajaran learning cycle $(5 \mathrm{E})$ berbasis kearifan lokal dan siswa yang mengikuti pembelajaran konvensional pada siswa kelas IV SD Gugus V Kecamatan Sukasada. Kemudian ditindaklanjuti Tabel 3 pada kolom sikap disiplin belajar, nilai Mean difference (I-J) sebesar 4.602 (bernilai positif) dengan signifikasi sebesar 0,017 lebih kecil dari $0,05(0,017<0,05)$ yang artinya kelompok eksperimen lebih baik dari kelompok kontrol.

Berdasarkan Uji Tests of Between-Subjects Effects Tabel 2, diperoleh nilai signifikasi hasil belajar IPA pada kolom Corrected Model sebesar 0,036 dan lebih kecil dari 0,05 (0,036< 0,05). Sehingga $H_{0}$ ditolak dan $H_{1}$ diterima. Jadi dapat disimpulkan bahwa, hasil analisis uji hipotesis 3 terdapat perbedaan hasil belajar IPA antara siswa yang mengikuti model pembelajaran learning cycle (5E) berbasis kearifan lokal dan siswa yang mengikuti pembelajaran konvensional pada siswa kelas IV SD Gugus V Kecamatan Sukasada. Kemudian ditindaklanjuti Tabel 3 pada kolom sikap disiplin belajar, nilai Mean difference (I-J) sebesar 8.545 (bernilai positif) dengan signifikasi sebesar 0,036 lebih kecil dari $0,05(0,036<0,05)$ yang artinya kelompok eksperimen lebih baik dari kelompok kontrol.

\section{Pembahasan}

Pada penelitian ini yang dibandingkan adalah: 1) sikap disiplin belajar siswa yang mengikuti model learning cycle (5E) berbasis kearifan lokal dengan siswa yang mengikuti pembelajaran konvensional, 2) hasil belajar IPA siswa yang mengikuti model learning cycle (5E) berbasis kearifan lokal dengan siswa yang mengikuti pembelajaran konvensional, dan 3) sikap disiplin belajar dan hasil belajar IPA siswa yang mengikuti model learning cycle (5E) berbasis kearifan lokal dengan siswa yang mengikuti pembelajaran konvensional secara simultan.

Berdasarkan penelitian yang telah dilakukan, secara deskriptif sikap disiplin belajar dan hasil belajar IPA siswa kelas IV yang mengikuti model learning cycle (5E) memiliki rata-rata skor sikap disiplin belajar dan hasil belajar lebih tinggi dari rata-rata skor sikap disiplin belajar dan hasil belajar IPA siswa yang mengikuti pembelajaran konvensional. Adapun pembahasannya sebagai berikut.

Pertama, perbedaan sikap disiplin belajar antara siswa yang mengikuti model learning cycle (5E) berbasis kearifan lokal dengan pembelajaran konvensional pada siswa kelas IV SD Gugus V Kecamatan Sukasada. Hasil analisis data sikap disiplin belajar penelitian menunjukan terdapat perbedaan sikap disiplin belajar antara siswa yang mengikuti pembelajaran model learning cycle (5E) berbasis kearifan lokal dengan siswa yang mengikuti pembelajaran konvensional. Setelah dilakukan pengamatan sikap disiplin belajar pada proses pembelajaran

Pengaruh Model Pembelajaran Learning Cycle (5e) Berbasis Kearifan Lokal Terhadap

Sikap Disiplin Belajar dan hasil belajar ipa siswa kelas iv sd gugus v Kecamatan sukasada 
dan pemberian kuesioner di akhir pembelajaran, didapatkan hasil nilai signifikasi sikap disiplin belajar pada kolom kelompok sebesar 0,017 dan lebih kecil dari 0,05 $(0,017<0,05$ Kemudian ditindaklanjuti pada kolom sikap disiplin belajar, nilai Mean difference (I-J) sebesar 4.602 (bernilai positif) dengan signifikasi sebesar 0,017 lebih kecil dari 0,05 $(0,017<0,05)$ yang artinya kelompok eksperimen lebih baik dari kelompok kontrol. Serta rata-rata nilai sikap disiplin belajar siswa yang mengikuti model learning cycle (5E) berbasis kearifan lokal sebesar 85,89. Sedangkan, siswa yang mengikuti pembelajaran konvensional memperoleh nilai rata-rata 81,61 Hal ini menunjukkan sikap disiplin belajar kelompok siswa yang dibelajarkan dengan model learning cycle (5E) berbasis kearifan lokal lebih tinggi dibandingkan dengan kelompok siswa yang mengikuti pembelajaran konvensional.

Sejalan dengan pendapat yang dikemukakan oleh Ditriguna, dkk. (2013) bahwa menerapkan model pembelajaran learning cycle (5E) dapat membuat siswa menjadi lebih aktif dalam proses pembelajaran dan pengaplikasiannya pun sudah berjalan efektif ini juga akan secarat tidak langsung akan membuat suasana kelas menjadi menarik jauh dari kesan jenuh pada saat pembelajaran. Berdasarkan penelitian yang telah dilakukan dan diperkuat oleh Ditriguna, dkk. (2013), maka model learning cycle (5E) berbasis kearifan lokal pada proses pembelajaran berpengaruh signifikan terhadap sikap disiplin belajar siswa.

Kedua, perbedaan hasil belajar IPA antara siswa yang mengikuti model learning cycle (5E) berbasis kearifan lokal dengan pembelajaran konvensional pada siswa kelas IV Gugus V Kecamatan Sukasada. Hasil analisis data hasil belajar IPA menunjukkan terdapat perbedaan hasil belajar IPA antara siswa yang mengikuti model learning cycle (5E) berbasis kearifan lokal dengan pembelajaran konvensional. Siswa yang mengikuti mengikuti model learning cycle (5E) berbasis kearifan lokal memperoleh nilai signifikasi hasil belajar IPA pada kolom kelompok sebesar 0,036 dan lebih kecil dari $0,05(0,036<0,05)$. Sehingga $\mathrm{H}_{0}$ ditolak dan $\mathrm{H}_{1}$ diterima. Kemudian ditindaklanjuti pada kolom sikap disiplin belajar, nilai Mean difference (I-J) sebesar 8.545 (bernilai positif) dengan signifikasi sebesar 0,036 lebih kecil dari 0,05 $(0,036<0,05)$ yang artinya kelompok eksperimen lebih baik dari kelompok kontrol. Serta hasil belajar rata-rata yaitu 67,33 lebih tinggi dibandingkan dengan siswa yang mengikuti pembelajaran konvensional yang hanya memperoleh nilai rata-rata 59,36. Hal ini menunjukkan hasil belajar kelompok siswa yang dibelajarkan dengan model learning cycle (5E) berbasis kearifan lokal lebih tinggi dibandingkan dengan hasil belajar kelompok siswa yang mengikuti pembelajaran konvensional.

Qarareh (dalam Sugiantara, 2013:4) menyatakan bahwa hasil penelitian menunjukkan bahwa terdapat perbedaan yang signifikan hasil belajar IPA antara yang dibelajarkan dengan model learning cycle $5 E$ dan yang dibelajarkan dengan model konvensional dan Yopiani, dkk. (2013) menyimpulkan bahwa terdapat pengaruh model learning cycle (5E) (Engagement, Eksploration, Eksplanation, Elaboration, Evaluation) berbantuan media grafis terhadap hasil belajar PKn kelas V SDN 1 Kesiman. model pembelajaran learning cycle (5E) dapat merangsang dan menggali pengalaman siswa tentang budaya yang terdapat di masing-masing daerah tempat tinggalnya. Pembelajaran dengan menggunakan model pembelajaran learning cycle (5E) jauh lebih baik dari model pembelajaran tradisional/konvensional. Dengan demikian hasil penelitian menunjukan bahwa terdapat perbedaan yang signifikan hasil belajar PKn antara siswa yang dibelajarkan dengan model learning cycle (5E) berbantuan media grafis dan siswa yang dibelajarkan secara konvensional di SDN 1 Kesiman Berdasarkan penelitian yang telah dilakukan dan diperkuat oleh pendapat Yopiani, dkk. (2013), maka pengaruh model learning

Pengaruh Model Pembelajaran Learning Cycle (5e) Berbasis Kearifan Lokal Terhadap

Sikap Disiplin Belajar dan hasil belajar ipa siswa kelas iv sd gugus v Kecamatan sukasada 
cycle (5E) berbasis kearifan lokal pada proses pembelajaran berpengaruh terhadap hasil belajar IPA siswa.

Ketiga, perbedaan simultan sikap disiplin belajar dan hasil belajar ipa antara siswa yang mengikuti model learning cycle (5E) berbasis kearifan lokal dengan siswa yang mengikuti pembelajaran konvensional pada siswa kelas IV SD Gugus V Kecamatan Sukada. Hasil analisis data tentang sikap disiplin belajar dan hasil belajar IPA menunjukkan, terdapat perbedaan yang simultan antara siswa yang mengikuti model learning cycle $(5 \mathrm{E})$ berbasis kearifan lokal dengan siswa yang mengikuti pembelajaran konvensional. Siswa yang mengikuti model learning cycle (5E) berbasis kearifan lokal memperoleh hasil analisis, nilai F Pillai's Trace, Wilks' Lambda, Hotelling's Trace, Roy's Largest Root adalah 6,298 seluruhnya memiliki signifikansi 0,004 dan lebih kecil dari 0,05 $(0,004<0,05)$, hal ini menunjukkan terdapat perbedaan secara simultan sikap disiplin belajar dan hasil belajar IPA antara siswa yang mengikuti model learning cycle (5E) berbasis kearifan lokal dengan siswa yang mengikuti pembelajaran Konvensional pada siswa kelas IV SD Gugus V Sukasada. sikap disiplin belajar siswa merupakan unsur dasar yang penting bagi keberhasilan proses pembelajaran, sebab dengan adanya sikap disiplin siswa dalam belajar proses pembelajaran akan tercipta situasi belajar aktif.

Seorang pakar pendidikan, Cardak, dkk. (dalam Sadia, 2014:23) mengartikan bahwa model siklus belajar $5 \mathrm{E}$ merupakan suatu model pembelajaran yang berorientasi pada filsafat konstruktivisme. Model siklus belajar terdiri atas 5 fase aktivitas belajar yang dapat digunakan untuk memotivasi siswa dalam memahami gejala-gejala alam yang kompleks melalui pengalaman langsung. Melalui siklus belajar para siswa akan memperoleh kesempatan untuk memberi penjelasan, pada model siklus belajar memiliki beberapa fase yaitu (engagement, exploration, explanation, elaboration/extention, dan evaluation).Temuan ini didukung oleh penelitian Suniasih, dkk. (2013) yang menyimpulkan bahwa ada pengaruh model pembelajaran learning cycle 5E terhadap sikap ilmiah dan hasil belajar IPA siswa kelas V SD Negeri 5 Pedungan. Model ini dapat memberikan kesempatam bagi peserta didik untuk bekerjasama, terlibat aktif dalam pembelajaran guna mencapai tujuan pembelajaran serta proses pembelajaran jauh lebih baik dari model pembelajaran tradisional/konvensional dalam ilmu dasar.

Berdasarkan hasil penelitian yang telah dilakukan dan diperkuat oleh pendapat Suniasih, dkk. (2013), diketahui bahwa sikap disiplin belajar siswa meningkat setelah model learning cycle (5E) berbasis kearifan lokal, begitu pula dengan hasil belajar IPA siswa meningkat setelah mengikuti model learning cycle (5E) berbasis kearifan lokal. Hal ini menunjukkan bahwa terdapat perbedaan secara simultan sikap disiplin belajar dan hasil belajar IPA siswa. Semakin tinggi sikap disiplin belajar siswa, maka semakin tinggi pula pemahaman hasil belajar IPA yang dimiliki. Sebaliknya, semakin rendah sikap disiplin belajar siswa, maka semakin rendah pula hasil belajar IPA yang dimiliki. Sehingga dapat dikatakan terdapat perbedaan secara simultan sikap disiplin belajar dan hasil belajar IPA siswa.

\section{PENUTUP}

Berdasarkan pengujian hipotesis pada BAB IV diperoleh hasil penelitian ini adalah sebagai berikut: a) Terdapat perbedaan simultan sikap disiplin belajar dan hasil belajar IPA siswa kelas IV SDN Gugus V Kecamatan Sukasada, b) Terdapat perbedaan sikap disiplin belajar antara siswa yang mengikuti model pembelajaran learning cycle (5E) berbasis kearifan

Pengaruh Model Pembelajaran Learning Cycle (5e) Berbasis Kearifan Lokal Terhadap

Sikap Disiplin Belajar dan hasil belajar ipa siswa kelas iv sd gugus v Kecamatan sukasada 
lokal dengan siswa yang mengikuti pembelajaran konvensional pada siswa kelas IV SDN Gugus V Kecamatan Sukasada, c) Terdapat perbedaan hasil belajar IPA antara siswa yang mengikuti model pembelajaran learning cycle (5E) berbasis kearifan lokal dengan siswa yang mengikuti pembelajaran konvensional pada siswa kelas IV SDN Gugus V Kecamatan Sukasada. Berdasarkan uraian diatas, maka simpulan penelitian ini adalah terdapat pengaruh penerapan model pembelajaran learning cycle (5E) berbasis kearifan lokal terhadap sikap disiplin belajar dan hasil belajar IPA siswa kelas IV SDN Gugus V Kecamatan Sukasada. Berkenaan dengan hasil penelitian yang diperoleh maka beberapa saran yang dapat diajukan adalah sebagai berikut: a) siswa agar memanfaatkan kesempatan yang difasilitasi guru dengan berpartisipasi aktif dalam kegiatan pembelajaran menggunakan model learning cycle (5E) berbasis Kearifan Lokal, sehingga dapat membangun pengetahuannya sendiri, aktif dalam berpendapat dan meningkatkan sikap disiplin belajar dan hasil belajar IPA, b) agar lebih kreatif dan inovatif untuk memberikan fasilitas berupa sumber belajar dan kesempatan yang lebih besar bagi siswa pada pembelajaran dengan menggunakan model pembelajaran learning cycle (5E) berbasis kearifan lokal sehingga meningkatkan sikap disiplin belajar dan hasil belajar IPA, c) kepada kepala sekolah agar dapat menggunakan hasil penelitian ini sebagai pendukung sumber belajar guru dalam pembelajaran dengan menciptakan pembelajaran yang menarik di sekolah sehingga sekolah mampu meningkatkan sikap disiplin belajar dan hasil belajar IPA, d) kepada peneliti agar hasil penelitian ini digunakan sebagai referensi untuk melaksanakan penelitian selanjutnya atau menemukan inovasi kegiatan pembelajaran lainnya yang bermakna bagi siswa.

\section{DAFTAR RUJUKAN}

Agung, A. A. G. 2014. Metodologi Penelitian Pendidikan. Yogyakarta : Aditya Media Publishing.

Agung, A. A. G. 2011. Pengantar Evaluasi Pendidikan. Singaraja : Universitas Pendidikan Ganesha.

Astawan, I G dan Rati N W. 2016. "Pengaruh Model Pembelajaran Kuantum dan Teknik Merangkum Terhadap Penalaran Manusia." E-Journal PGSD Undiksh, Volume 3 (halaman 1-9). https://media.neliti.com/media/publications/85726-none-ce3fd1f6.pdf (diakses pada tanggal 24 Juni 2019).

Candiasa, I M. 2011. Pengujian Instrumen Penelitian Disertai Aplikasi ITEMAN dan BIGSTEPS. Singaraja: Undiksha Press.

Dewi, D. R, dkk. 2013."Pengaruh Model Pembelajaran Siklus Belajar (Learning Cycle) 5e Terhadap Hasil Belajar Ipa Siswa Kelas V Sdn 26 Pemecutan Denpasar Barat". Jurnal Mimbar PGSD Universitas Pendidikan Ganesha Jurusan PGSD. Vol. 1, No. 1.

Koyan, I. W. 2012. Statistik Pendidikan, Teknik Analisis Data Kuantitatif. Singaraja: Undiksha Press.

Putri, N K. W. D. 2018. "Pengaruh Model Pembelajaran Learning cycle (5E) Berbasis Kearifan Lokal Terhaap Kompetensi Pengetahuan IPA Siswa Kelas IV SDN Gugus Kapten

Pengaruh Model Pembelajaran Learning Cycle (5e) Berbasis Kearifan Lokal Terhadap

Sikap Disiplin Belajar dan hasil belajar ipa siswa kelas iv sd gugus v Kecamatan sukasada 
Kompyang Sujana Denpasar Barat Tahun Ajaran 2017/2018”. Skripsi. Tidak Diterbitkan. Fakultas Imu Pendidikan. Undiksha: Singaraja.

Sadia, I W. 2014. Model-model Pembelajaran Sains Kontruktivisme. Yogyakarta : Graha IImu.

Shoimin, A. 2014. 68 Model Pembelajaran Inovatif dalam Kurikulum 2013. Yogyakarta : ARRZZ MEDIA

Sisdiknas. Nomor 20 Tahun 2003. Undang-undang Sisdiknas (Sistem Pendidikan Nasional) 2003 (UU RI No. 20 Th. 2003). Jakarta : Sinar Grafika.

Sugiantara, I P. 2013. "Pengaruh Model Pembelajaran Learning cycle (5E) Terhadap Hasil Belajar IPA Siswa Kelas V Di Gugus VII Kecamatan Buleleng”. Jurnal Mimbar PGSD Universitas Pendidikan Ganesha Jurusan PGSD. Vol. 1, No. 1.

Suja, I A. 2010. Kearifan Lokal Sains Asli Bali. Denpasar : Paramita.

Suniasih, N W. 2013. "Pengaruh Model Pembelajaran Learning Cycle 5E Terhadap Sikap IImiah dan Hasil Belajar IPA Siswa Kelas V di SDN 5 Pedungan Denpasar". Jurnal Mimbar PGSD Universitas Pendidikan Ganesha Jurusan PGSD. Vol. 1, No. 1.

Yuniari, N M. D. 2014. "Pengaruh Penarapan Pendekatan Pembelajaran Konstektual Berbasis Kearifan Lokal Terhadap Hasil Belajar PKN Siswa Kelas V SD Gugus VI Abiansemal". Jurnal Mimbar PGSD Universitas Pendidikan Ganesha Jurusan PGSD. Vol. 2, No. 1.

Yopiani, P. S, dkk. 2013. "Pengaruh Model Learning Cycle 5e (Engagement, Exsploration, Explanation, Elaboration, Evaluation) Berbantuan Media Grafis Terhadap Hasil Belajar Pkn Kelas V Sd N 1 Kesiman". Jurnal Mimbar Pgsd Universitas Pendidikan Ganesha Jurusan Pgsd. Vol. 1, No. 1.

Pengaruh Model Pembelajaran Learning Cycle (5e) Berbasis Kearifan Lokal Terhadap 